\title{
KINERJA KOMUNIKASI DATA PAKET SISTEM CDPD OVERLAY PADA SISKOMSEL ANALOG
}

\author{
Rina Pudji Astuti \\ Jurusan Teknik Elektro Sekolah Tinggi Teknologi Telkom, Bandung \\ rpa@stttelkom.ac.id
}

\begin{abstract}
Abstrak
Sistem komunikasi selular selain dapat digunakan sebagai alat komunikasi suara juga untuk komunikasi data. Salah satu penerapan sistem komunikasi data tersebut adalah sistem CDPD (Cellular Digital Packet Data) yang dibuat overlay pada sistem komunikasi selular analog, yaitu AMPS. Sistem tersebut menjadi fokus pada penelitian ini, yang melakukan simulasi secara teoritis mengenai kinerja sistem komunikasi data tersebut, yaitu meliputi pengaruh penerapan sistem ini terhadap pemakai komunikasi suara, throughput, delay rata-rata dan rugi-rugi trafik suara ternormalisasi terhadap rugi-rugi trafik tanpa penerapan CDPD. Ada 2 macam algoritma distribusi kanal yang diterapkan pada sistem CDPD ini, yaitu algoritma dedicated channel dan algoritma frequency hopping. Dari hasil simulasi terlihat bahwa penerapan sistem ini dengan algoritma dedicated channel akan mengurangi jumlah kanal yang melayani trafik suara, sehingga $\boldsymbol{P}_{\text {block }}$ dari trafik suara akan naik. Penggunaan antena omnidirectional memberikan pengaruh lebih baik terhadap kualitas trafik suara dari pada penggunaan antena sektor. Sedangkan dengan algoritma frequency hopping, terlihat bahwa karena sistem ini memanfaatkan kanal yang tidak digunakan oleh trafik suara, dan kanal yang digunakan oleh sistem ini dianggap kosong oleh trafik suara, maka penerapan sistem ini akan menaikkan penggunakan kanal sistem selular, sehingga menurunkan C/I. Penggunaan antena sektor akan menyebabkan kinerja sistem CDPD lebih baik dari pada penggunaan antena omnidirectional, tetapi akan menyebabkan rugi-rugi trafik suara ternormalisasi yang lebih buruk dari pada penggunaan antena sektor.
\end{abstract}

Kata Kunci: aplikasi sistem komunikasi data, CDPD, overlay

\begin{abstract}
A cellular communication system is not only fit to be used as a voice communication but also as data communication system. One of data communication system applications is CDPD (Cellular Digital Packet Data). Focus of the research is a CDPD system overlaid upon an analog cellular system, AMPS. Theoretical simulation was used to verify the performances of the data communication on voice communication user, throughput, average delay and normalised voice traffic loss. Two categories of channel assignment are used on the CDPD system, i.e. a dedicated channel algorithm and frequency hopping algorithm. The simulations show that the application of the dedicated channel algorithm reduce the number of voice channels, however the blocking probability of voice traffic, $P_{b l o c k}$, increase. The use of omni-directional antenna gives a better voice traffic quality than using a sectoral antenna. On the other hand, the application of frequency hopping algorithm increase the channels utilisation due to unused voice channel whic be employed to carry data traffic, but at a cost of decrease of carrier to interference ratio C/I. The use of sector antenna will give a CDPD system better performance than an omni-directional antenna, but increase normalised voice traffic loss.
\end{abstract}

Keywords: data communication system application , CDPD, overlay

1. Pendahuluan

Sejalan dengan perkembangan sistem informasi saat ini, sistem komunikasi selular diharapkan tidak hanya dapat digunakan sebagai alat komunikasi suara saja. Tetapi juga dapat digunakan sebagai alat komunikasi data, antara Mobile-End System (M-ES) dengan M-ES lain, maupun antara M-ES dengan Fixed_End System(FES), misalnya berupa $e$-mail, fax, file transfer antar bank maupun instansi, yang tidak berkendala waktu dan cara transmisinya secara burst. Untuk menunjang kebutuhan tersebut di atas, saat ini banyak dikembangkan sistem komunikasi dData pada sistem komunikasi selular.
Salah satu metoda yang banyak digunakan dan mudah dikembangkan lebih lanjut adalah penerapan sistem komunikasi data secara overlay pada sistem komunikasi selular, dengan kanal data yang dapat menggunakan kanal suara yang 'kosong'. Salah satu sistem yang menerapkan metoda ini adalah CDPD, yang dipasang overlay terhadap sistem komunikasi selular analog, AMPS.

Pada penelitian ini dilakukan simulasi untuk mengetahui pengaruh penerapan komunikasi data terhadap pemakai komunikasi suara dan kinerja sistem komunikasi data meliputi: throughput, delay rata-rata dan rugi-rugi trafik ternormalisasi terhadap rugi-rugi trafik tanpa penerapan CDPD. Asumsi yang digunakan: proses kedatangan adalah Poisson 
dan waktu pelayanan mempunyai distribusi exponensial negatif

\section{Cellular Digital Packet Data (CDPD)}

CDPD dikembangkan dengan pertimbangan sedapat mungkin memanfaatkan infrastruktur komunikasi selular yang ada (wireless public data network) dan dapat berinterkoneksi dengan sistem komunikasi data yang telah ada. Penerapan secara overlay memungkinkan pemanfaatan perangkat komunikasi yang ada di AMPS, seperti perangkat modulasi dan perangkat radionya. Untuk berinterkoneksi dengan jaringan komunikasi data yang lain, misalnya LAN, Internet, dan lain-lain digunakan protokol IP (Internet Protocol) dan CLNP (Connectionless Network Protocol). Selain itu jaringan CDPD dapat digunakan sebagai network infrastructure backbone bagi sistem CDMA dan PCS atau dapat juga digabungkan dengan sistem D-AMPS yang menggunakan sistem E-TDMA dengan menambahkan perangkat Circuit Switched CDPD (CS-CDPD). Arsitektur jaringan CDPD dapat dijelaskan seperti pada Gambar 1.

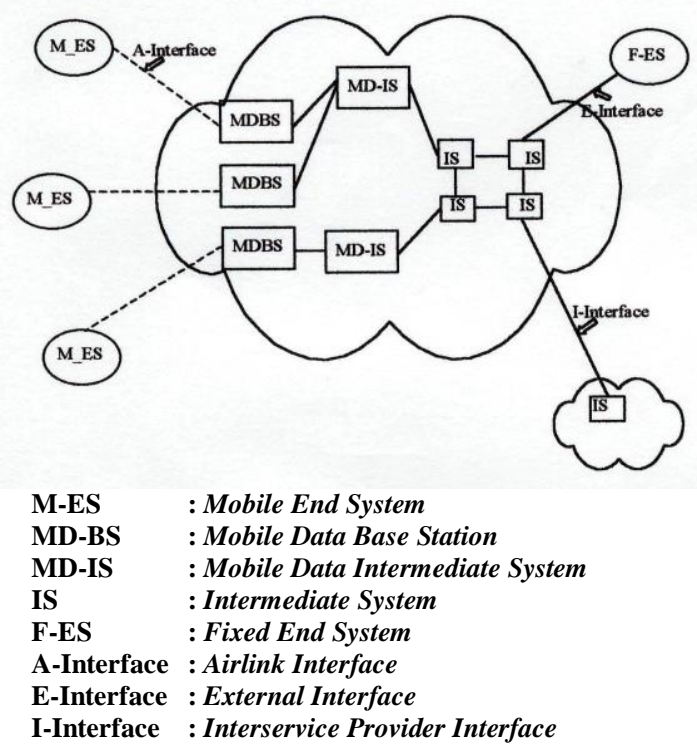

Gambar 1. Model Arsitektur Jaringan CDPD

IS berfungsi sebagai lapisan jaringan seperti yang didefinisikan oleh model referensi ISO, yaitu mencari path melalui susunan IS yang terhubung, sedemikian hingga dapat dicapai M-ES yang dituju. Jadi fungsi IS meliputi perhitungan route, pembentukan informasi menjadi paket data, penyusunan paket data yang diterima menjadi informasi kembali dan mengurangi terjadinya kongesti. Pada arsitektur CDPD, IS melakukan routing antar-MD-IS dengan menggunakan CLNP datagram dan melakukan routing antara MD-IS dan F-ES dengan menggunakan IP. Selain itu IS juga dapat melakukan routing antar MD-IS dan MD-BS.

\section{Pemodelan Algoritma Distribusi Kanal dan Aliran Informasi pada Penerapan CDPD}

Sistem CDPD dirancang sebagai sistem yang independent yang dapat dipadukan dengan sistem selular lain, misalnya D-AMPS, E-TDMA, atau CDMA. Pada penelitian ini pembahasan hanya difokuskan pada penerapan CDPD overlay pada sistem AMPS, dengan diagram blok sebagaimana diperlihatkan pada Gambar 2.

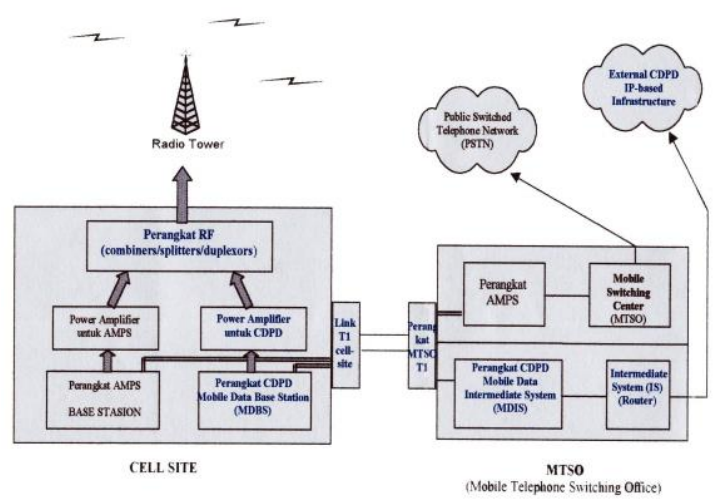

Gambar 2. Diagram Blok Penerapan Sistem CDPD Overlay pada Sistem AMPS

\subsection{Model Algoritma Distribusi Kanal}

Pola alokasi frekuensi pembawa pada jaringan AMPS dan CDPD adalah sama, tetapi mekanisme pemilihan kanal CDPD terpisah dari sistem AMPS. Sistem CDPD dirancang untuk menggunakan kanal yang tidak digunakan sistem AMPS, tanpa berkomunikasi langsung dengan sistem AMPS. Sehingga pada sistem CDPD perlu diterapkan teknik yang disebut $r$-sniffing untuk mendeteksi apakah kanal-kanal AMPS 'kosong' atau 'sibuk'. Ada 2 algoritma alokasi frekuensi yang digunakan pada sistem CDPD, yaitu :

1) Algoritma kanal data menempati kanal tertentu (dedicated channel)

2) Algoritma frequency hopping (shared channel)

\subsubsection{Model Algoritma Dedicated Channel}

Pada algoritma ini ditetapkan suatu/beberapa kanal AMPS untuk digunakan oleh jaringan CDPD. Sehingga tidak perlu diimplementasikan suatu prosedur tertentu untuk memonitor apakah dedicated channel (kanal "D") tersebut digunakan oleh jaringan lain. Tetapi penerapan algoritma ini akan mengurangi jumlah kanal untuk layanan suara.

\subsubsection{Model Algoritma Frequency Hopping}

Algoritma ini dirancang dengan pertimbangan sebagai berikut :

a. trafik suara tetap menjadi prioritas

b. menghindari interferensi dengan kanal suara

c. tidak mengurangi throughput dari trafik suara 
Pada algoritma ini sistem CDPD memonitor idle flag yang secara periodik dikirim oleh Base Station. Jika sistem CDPD mendeteksi kanal kosong (misal $f_{0}$ ) maka sistem CDPD akan menempati kanal tersebut, selanjutnya jika sistem CDPD mendeteksi ada panggilan suara yang akan menggunakan $f_{0}$, maka CDPD akan menerapkan mekanisme switched off carrier. Kemudian akan mencari kanal lain yang kosong (misal $f_{1}$ ).

\subsection{Model Aliran Informasi CDPD}

\subsubsection{Model Aliran Informasi CDPD pada Algoritma Dedicated Channel}

Penerapan algoritma ini akan mengurangi jumlah kanal untuk layanan suara, karena kanal "D" yang telah didefinisikan sebagai kanal data tidak diperhitungkan dalam perebutan kanal pada layanan suara. Sehingga jumlah kanal untuk panggilan suara adalah $(n-D)$ kanal. Gambar 3 menjelaskan model aliran informasi untuk $\mathrm{D}=2$ pada penggunaan algoritma dedicated channel.

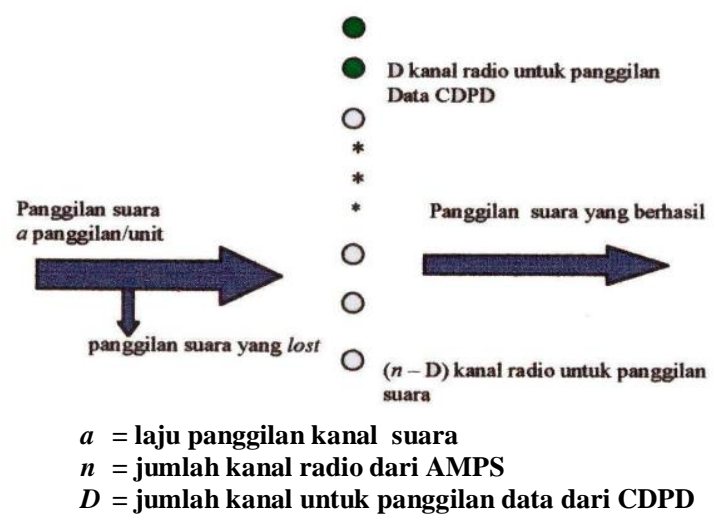

Gambar 3. Model Aliran Informasi CDPD pada Algoritma Dedicated Channel

Pada model aliran informasi ini, $n$ kanal radio dalam sektor atau cell dimodelkan sebagai $n$ buah pelayan dalam susunan paralel tanpa buffer. Kedatangan panggilan suara pada sistem ini diasumsikan sebagai proses Poisson dengan laju kedatangan $a$ panggilan/unit. Waktu pelayanan untuk panggilan suara diasumsikan terdistribusi eksponesial negatif dengan rata-rata 1 unit.

\subsubsection{Model Aliran Informasi CDPD pada Algoritma Frequency Hopping}

Pada algoritma frequency hopping, trafik suara tetap memiliki prioritas layananyang lebih tinggi dari pada trafik data. Adapun interaksi dari kanal suara dan kanal data CDPD dapat diperlihatkan pada Gambar 4. Jika terjadi kedatangan panggilan data dan mendapatkan bahwa semua kanal radio ( $n$ kanal) terpakai oleh panggilan suara, maka panggilan tersebut akan lost. Dengan catatan bahwa kanal radio yang sedang digunakan oleh kanal CDPD dianggap sebagai kanal kosong oleh sistem AMPS.

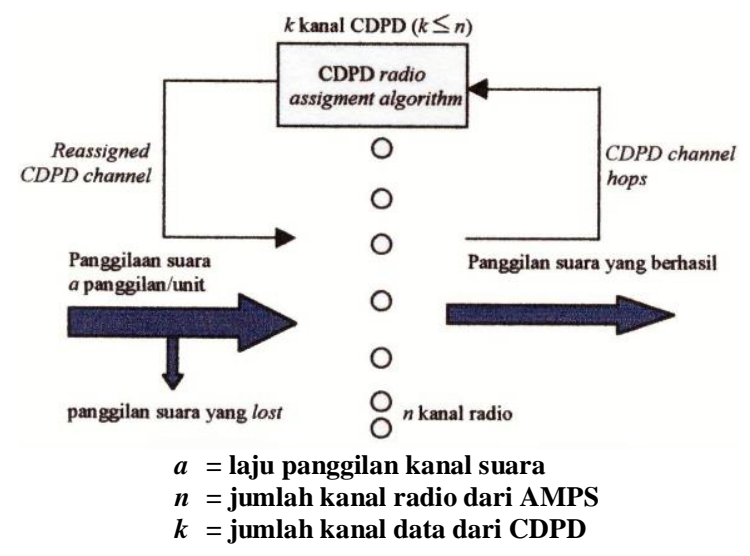

Gambar 4. Model Aliran Informasi CDPD pada Algoritma Frequency Hopping

\subsection{Pengaruh Penerapan CDPD terhadap Panggilan Suara}

Metoda perhitungan pengaruh penerapan CDPD dengan algoritma dedicated channel tidak dibahas secara khusus. Karena pada algoritma ini trafik CDPD diperlakukan sama dengan trafik suara, sehingga kinerja sistem selular secara keseluruhan tidak berubah, tetapi hanya akan mengurangi jumlah kanal untuk trafik suara, maka blocking probability kanal suara akan naik.

Pada algoritma frequency hopping, jika jumlah kanal CDPD pada sector/cell AMPS dinaikkan, tidak akan menurunkan jumlah kanal kosong yang bisa digunakan untuk panggilan suara. Tetapi akan menaikkan perebutan kanal kosong antar kanalkanal CDPD tersebut, sehingga blackout setiap kanal CDPD akan naik, sebaliknya active state setiap kanal akan turun.

Dengan menggunakan model aliran informasi pada sub bab 3.2.2, dapat dihitung peluang $i$ kanal radio digunakan oleh panggilan suara (blocking probability), $P_{i}[6]$ :

$$
P_{i}=\frac{\frac{a^{i}}{i !}}{\sum_{j=0}^{n} \frac{a^{j}}{j !}}
$$

dengan:

$a=$ laju panggilan kanal suara (dengan waktu rataan layanan panggilan suara 1 unit waktu) $n=$ jumlah kanal radio dari AMPS

Sebuah kanal CDPD mempunyai 2 kemungkinan keadaan yaitu blackout (jika kanal digunakan oleh panggilan suara) dan active period. Sehingga fraksi waktu sebuah kanal CDPD aktif, $T_{A}$ adalah:

$$
T_{A}=\frac{T_{a}}{T_{a}+T_{b}}
$$

dengan: 


$$
\begin{aligned}
& T_{a}=\frac{k-L_{b}}{\lambda_{b}} \\
& L_{b}=\sum_{i=0}^{k-1} P_{n-1}(k-i) \\
& \lambda_{b}=\sum_{i=0}^{k-1} P_{n-i}(n-i)=a \sum_{i=n-k}^{n-1} P_{i} \\
& T_{b}=\frac{L_{b}}{\lambda_{b}} \\
& k=\text { jumlah kanal data dari CDPD }
\end{aligned}
$$

\subsection{Kinerja Komunikasi Data Paket}

Kinerja Komunikasi Data Paket pada sistem CDPD sangat dipengaruhi oleh protokol yang digunakan pada airlink. Aliran data pada kanal arah maju bersifat kontinyu dan tetap. Sebaliknya aliran data pada kanal arah balik, karena beberapa M-ES secara bersamaan dapat mengakses sebuah kanal kosong, sehingga terdapat kemungkinan terjadinya collision. Sehingga batas bawah channel throughput dari sistem CDPD ditentukan oleh throughput pada kanal arah balik.

Oleh sebab itu pembahasan kinerja sistem CDPD dibatasi hanya pada arah balik dan diasumsikan hanya ada sebuah MDBS pada setiap sel. Aliran data pada kanal arah balik dari sistem CDPD mengikuti mekanisme DSMA (Digital Sense Multiple Access). M-ES melakukan digitally sense terhadap kanal arah balik, dengan membentuk control flag berupa busy/idle dan decode-status flag.

\subsubsection{Throughput}

Throughput diasumsikan sebagai sama dengan channel throughput, yang didefinisikan sebagai perbandingan antara waktu rata kanal melakukan transmisi data yang sukses dalam satu cycle $T_{\text {success }}$ dengan panjang cycle rata-rata $T_{\text {cycle }}$, ditulis dalam Persamaan (7).

$$
\begin{aligned}
& T_{\text {throughput }}=\frac{T_{\text {success }}}{T_{\text {cycle }}} \\
& T_{\text {success }}=\sum_{i=0}^{N} \psi_{i} \cdot P_{\text {trans_success }}(i) .(\tau+1) \\
& T_{\text {cycle }}=\sum_{i=0}^{N} \psi_{i} \cdot\left(\left(1-\delta_{i}\right)^{-1}+P_{\text {trans_success }}(i) \cdot \tau+\right. \\
& \sum_{k=1}^{l} \sum_{j}^{b l o k} g_{i j}(k) \cdot \tau_{c}(k)+1 \\
& P_{\text {trans_success }}(i)=\left(1-\delta_{i}\right)^{-1} \cdot(1-\varepsilon)^{l_{-} \text {blok }} \\
& \left((N-i) \cdot \alpha \cdot(1-\alpha)^{N-i-1} \cdot(1-\beta)^{i}\right. \\
& \left.+i \cdot \beta \cdot(1-\beta)^{i-1} \cdot(1-\alpha)^{N-i}\right) \\
& \tau=(6,41 \text { l_blok })+1 \text { (mikro slot) } \\
& =\text { panjang data } \\
& \text { l_blok = panjang blok data } \\
& \tau_{c} \cong 15+7(e-1) \text { (mikro slot) } \\
& =\text { adalah collision window }
\end{aligned}
$$

Elemen matrik $S$

$e$ menunjukkan lokasi blok yang salah

$\varepsilon \quad$ laju block error

$\delta_{\mathrm{i}}$ peluang terminal M_ES sibuk , jika $i$ pelanggan backlog

$\left(1-\delta_{i}\right)^{-1}$ rata-rata periode idle

$N$ jumlah kanal per sel atau sektor

$\alpha$ peluang pembangkitan data oleh M-ES pada kondisi idle state

$1 / \beta$ (slot) adalah rataan geometric distribution (memoryless) akibat delay retransmisi

$$
\Psi=\left[\psi_{0}, \psi_{1}, \psi_{2}, \ldots, \psi_{N}\right]
$$$$
\Psi=\Psi \cdot P_{\text {transmisi }}
$$

$=$ steady state probability distribution dari $N_{b}(t)$

$N_{b}(t)$ adalah jumlah M-ES yang mengalami backlog pada saat $t$.

$$
\begin{aligned}
P_{\text {transmisi }} & =S \cdot B^{\tau+1} \cdot W+\sum_{k=1}^{l} G(k) \cdot B^{\tau_{c}(k)+1} \\
& =\text { transitional probability matrix } \\
P_{\text {transisi } i_{i j} i j} & =P_{r} \cdot\left[N\left(t_{0}+I+T\right)=j \mid N\left(t_{0}\right)=i\right]
\end{aligned}
$$

$P_{\text {transmiss } i j}$ adalah peluang jumlah perubahan pelanggan backlog $i$ pada awal cycle menjadi $j$ pada akhir cycle

$$
\begin{gathered}
s_{i j}=P_{r} \cdot\left[N\left(t_{0}+I\right)=j_{-} d a n_{-}\right. \text {transmisi_sukses } \\
\left.N\left(t_{0}+I-1\right)=i\right]
\end{gathered}
$$

Elemen matrik $G(k)$

$$
\begin{array}{r}
g_{i j}(k)=P_{r} \cdot\left[N\left(t_{0}+I\right)=j_{-} d a n_{-} d e c o d e_{-} b l o k_{-}\right. \\
\left.k e_{-} k_{-} g a g a l \mid N\left(t_{0}+I-1\right)=i\right] \quad(17)
\end{array}
$$

Elemen matrik $B$

$$
\begin{aligned}
& b_{i j}=P_{r} \cdot\left[(N-i) \_M E S_{-} i d l e_{-} d i t a m b a h_{-}\left(j_{-} i\right)_{-}\right. \\
& \text {pelanggan_back } \log _{-} b a r u \_d a l a m_{-} s l o t_{-} \\
& \text {sibuk_dengan_i_MES_back } \log ]
\end{aligned}
$$

Elemen matrik $W$

$$
\begin{gathered}
w_{i j}=P_{r} \cdot\left[N\left(t_{0}+I+T\right)=i-1 \mid N\left(t_{0}+I-1\right)=i_{-}\right. \\
\text {dan_transmisi_sukses }]
\end{gathered}
$$

\subsubsection{Delay Rata-Rata}

Delay rata-rata dari kanal arah balik didefinisikan sebagai delay yang disebabkan oleh kondisi M-ES yang mengalami defer mode dan backoff mode, sehingga diperlukan transmisi data. Pada penelitian ini disederhanakan sebagai berikut:

a. defer mode dan backoff mode diperlakukan sama dan didefinisikan sebagai backlog mode

b. data yang mengalami backlog akan mengalami delay karena proses retransmisi dengan geometric distribution (memoryless) dengan rataan $1 / \beta$ slot

c. dengan kata lain setiap M_ES yang mengalami backlog akan mendeteksi kanal arah balik dengan peluang $\beta$ 
Delay rata-rata pada kanal arah balik, ternormalisasi terhadap panjang paket data, $D_{\text {delay }}$, didefinisikan sebagai:

$$
D_{\text {delay }}=\frac{N_{\text {backlog }}}{T_{\text {throughput }}}
$$

dimana :

$$
\begin{aligned}
N_{\text {backlog }} & =\text { rata-rata kanal mengalami backlog } \\
& =\frac{1}{T_{\text {cycle }}} \sum_{i=0}^{N} \psi_{i} \cdot\left(\frac{i}{1-\delta_{i}}+B_{-} \text {sibuk }_{i}\right)
\end{aligned}
$$

$N=$ jumlah kanal per sel atau sector

B_sibuk = jumlah kanal backlog yang diharapkan terjadi pada seluruh slot selama periode sibuk

$$
\begin{aligned}
B_{-} \text {sibuk }= & \sum_{m=0}^{\tau} \sum_{j=i}^{N} j \cdot\left(S \cdot B^{m}\right)_{i j}+ \\
T_{\text {throughpul }}= & \sum_{k=1}^{l} \sum_{m=0}^{\text {blok } \tau_{C}(k)} \sum_{j=i}^{N} j \cdot\left(G(k) \cdot B^{m}\right)_{i j} \\
& \text { pada kanel throughput }
\end{aligned}
$$

\subsubsection{Rugi-rugi Trafik Suara Ternormalisasi}

Sebelum menghitung rugi-rugi trafik ternormalisasi, terlebih dahulu ditentukan berapa trafik suara maksimum yang dapat dilayani, jika tanpa CDPD. Selanjutnya ditentukan rugi-rugi trafik ternormalisasi pada trafik suara maksimum, untuk algoritma dedicated channel dan frequency hopping. Trafik suara maksimum yang dapat dilayani dibatasi oleh dua faktor :

a. efisiensi trunking, yang dinyatakan oleh blocking probability $\left(P_{\text {block }}\right)$

b. efisiensi kualitas, yang dinyatakan dengan carrier to interference ratio $(C / I)$

\subsubsection{Rugi-rugi Trafik Suara Ternormalisasi untuk Sistem Dedicated Channel}

Penerapan algoritma dedicated channel akan mengurangi jumlah kanal yang melayani trafik suara, sebesar "D" kanal yang diperuntukkan untuk sistem CDPD.

Metoda perhitungan rugi-rugi trafik suara ternormalisasi, mengikuti faktor pembatas yang terjadi pada sistem selular tersebut, yaitu efisiensi trunking atau efisiensi kualitas $(C / I)$.

Jika faktor pembatas sistem selular tersebut adalah efisiensi trunking, maka rugi-rugi trafik suara ternormalisasi didefinisikan sebagai:

$$
\Gamma=\frac{E\left(N, P_{\text {block }}\right)-E\left(N-D, P_{\text {block }}\right)}{E\left(N, P_{\text {block }}\right)}
$$

Jika faktor pembatas sistem selular tersebut adalah efisiensi kualitas/interferensi, maka rugirugi trafik suara ternormalisasi didefinisikan sebagai:

$$
\Gamma=\frac{E\left(N, C / I_{\text {threshold }}\right)-E\left(N-D, C / I_{\text {threshold }}\right)}{E\left(N, C / I_{\text {threshold }}\right)}
$$

\subsubsection{Rugi-rugi Trafik Suara Ternormalisasi untuk Sistem Frequency Hopping}

Penerapan sistem CDPD dengan algoritma frequency hopping tidak akan mengurangi jumlah kanal yang melayani trafik suara, tetapi akan memperbesar interferensi. Metoda perhitungannya adalah sebagai berikut:

a. Penggunaan kanal $\rho_{\text {data }}$ oleh sistem CDPD didefinisikan sebagai penggunaan kanal selular oleh sistem CDPD karena transmisi yang sukses, dengan peluang $P_{\text {trans_success }}(i)$ pada Persamaan (10), yaitu :

$$
\rho_{\text {data }}=\frac{E\left(N, P_{\text {block }}\right)}{N} P_{\text {trans_success }}(i)
$$

b. Jika diasumsikan semua kanal $N$ dapat digunakan oleh trafik data, maka penggunaan kanal data total dinyatakan oleh :

$$
\rho_{\text {cdpd }}=\frac{\rho_{\text {data }}+\Delta \rho_{f h}}{N}
$$

dengan $\Delta \rho_{f h}$ faktor tambahan penggunaan kanal karena blok data yang hilang selama proses hop dan harus dikirim ulang.

c. Penggunaan kanal total (trafik suara dan CDPD) dengan faktor pembatas efisiensi trunking dinyatakan oleh :

$$
\rho_{f}=\rho+\rho_{c d p d}
$$

Sedangkan jika faktor pembatasnya adalah efisiensi kualitas $(C / I)$ dinyatakan oleh :

$$
\rho_{f}=10^{\frac{-\Delta I_{k}}{10}}+\rho_{c d p d}
$$

d. Jika pemakaian kanal total tidak menyebabkan kualitas sinyal kurang dari batas terendah $C / I_{\text {threshold }}$, maka rugi-rugi trafik suara dianggap nol. Jika terjadi kondisi sebaliknya, maka trafik suara harus dikurangi untuk dapat menyalurkan trafik CDPD. Rugi-rugi trafik suara adalah:

$$
\Gamma=\frac{E\left(N, C / I_{\text {threshold }}\right)-N \cdot\left(10^{\left(\Delta I_{k} / 10\right)}-\rho_{\text {cdpd }}\right)}{E\left(N, C / I_{\text {threshold }}\right)}
$$

\section{Hasil Simulasi Kinerja Sistem Komunikasi Data CDPD}

Simulasi sistem komunikasi data CDPD diasumsikan untuk macam dua kondisi :

a. Digunakan antena omnidirectional, dengan jumlah kanal AMPS $N=54$ kanal

b. Digunakan antena 3 sector $120^{\circ}$, dengan jumlah kanal AMPS $N=19$ kanal 


\subsection{Pengaruh CDPD pada Panggilan Suara}

\subsubsection{Pengaruh Penerapan CDPD dengan Algoritma Dedicated Channel}

Tabel 1. Pengaruh CDPD Dedicated Channel terhadap $P_{\text {block }}$ Trafik Suara

\begin{tabular}{|c|c|c|c|}
\hline $\begin{array}{l}\text { Jumlah } \\
\text { Kanal } \\
\text { AMPS }\end{array}$ & $\begin{array}{c}P_{\text {block }} \text { Trafik Suara } \\
\text { Tanpa CDPD }\end{array}$ & $\begin{array}{l}\text { Jumlah } \\
\text { Kanal "D" }\end{array}$ & $\begin{array}{c}P_{\text {block }} \text { Trafik Suara } \\
\text { dengan CDPD }\end{array}$ \\
\hline \multirow{6}{*}{19} & \multirow{3}{*}{$1 \%$} & 1 & $1,71 \%$ \\
\hline & & 2 & $2,79 \%$ \\
\hline & & 3 & $4,34 \%$ \\
\hline & \multirow{3}{*}{$2 \%$} & 1 & $3,16 \%$ \\
\hline & & 2 & $4,75 \%$ \\
\hline & & 3 & $6,88 \%$ \\
\hline \multirow{6}{*}{54} & \multirow{3}{*}{$1 \%$} & 1 & $1,32 \%$ \\
\hline & & 2 & $1,70 \%$ \\
\hline & & 3 & $2,17 \%$ \\
\hline & \multirow{3}{*}{$2 \%$} & 1 & $2,51 \%$ \\
\hline & & 2 & $3,10 \%$ \\
\hline & & 3 & $3,78 \%$ \\
\hline
\end{tabular}

Dari hasil simulasi di Tabel 1 terlihat bahwa pengaruh CDPD algoritma dedicated channel terhadap kualitas layanan suara sangat berarti, terutama jika digunakan antena sector. Demikian pula jika sistem selular tersebut mempunyai $P_{\text {block }}$ yang lebih besar, sistem selular akan lebih sensitif terhadap pemilihan harga kanal " $\mathrm{D}$ ".

\subsubsection{Pengaruh Penerapan CDPD dengan Algoritma Frequency Hopping}

Gambar 5 menampilkan contoh hasil perhitungan panjang waktu rata-rata kanal CDPD aktif dengan asumsi call holding time mempunyai rataan 1 unit satuan (ternormalisasi terhadap call holding time), sebagai fungsi dari jumlah kanal AMPS per sel atau sektor. Dimana panjang waktu rata-rata kanal CDPD aktif diperoleh dengan mempergunakan persamaan (3).

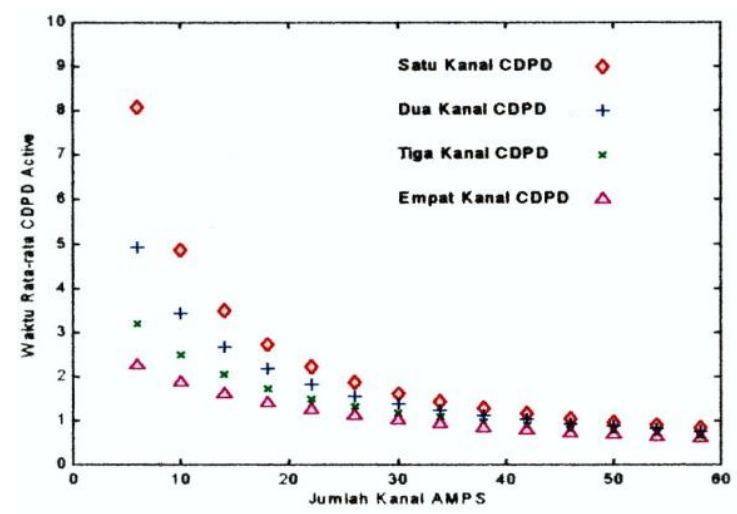

Gambar 5. Panjang Waktu Rata-rata Kanal CDPD Aktif $\left(P_{\text {block }}=2 \%\right)$

Semakin banyak jumlah kanal CDPD atau semakin banyak jumlah kanal AMPS pada suatu sel akan memperpendek waktu rata-rata kanal CDPD tersebut dapat aktif mengirimkan data.

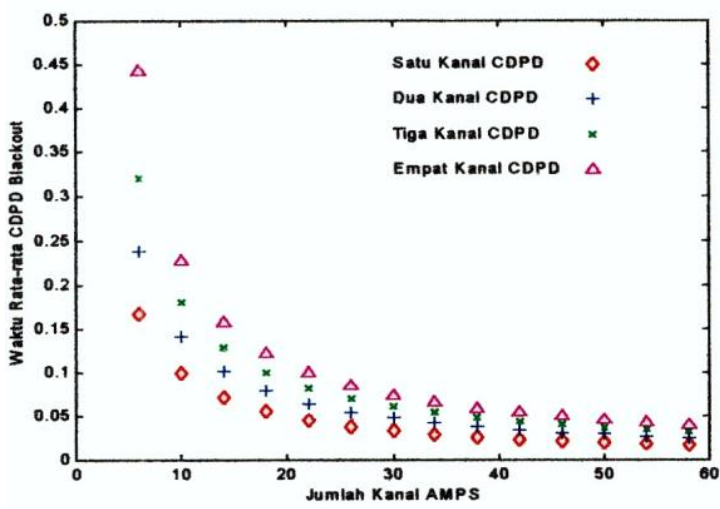

Gambar 6. Panjang Waktu Rata-rata Kanal CDPD Mengalami Blackout $\left(P_{\text {block }}=2 \%\right)$

Gambar 6 menampilkan hasil perhitungan panjang waktu rata-rata kanal CDPD mengalami blackout, diasumsikan call holding time mempunyai rataan 1 unit satuan (ternormalisasi terhadap call holding time), sebagai fungsi dari jumlah kanal AMPS per sel atau sector. Panjang waktu rata-rata kanal CDPD mengalami blackout diperoleh dengan mempergunakan persamaan (6).

Dari hasil perhitungan terlihat bahwa panjang waktu rata-rata CDPD mengalami blackout, berlawanan dengan hasil perhitungan kanal CDPD aktif. Karena panjang waktu CDPD aktif ditambah waktu CDPD mengalami blackout merupakan 1 cycle.

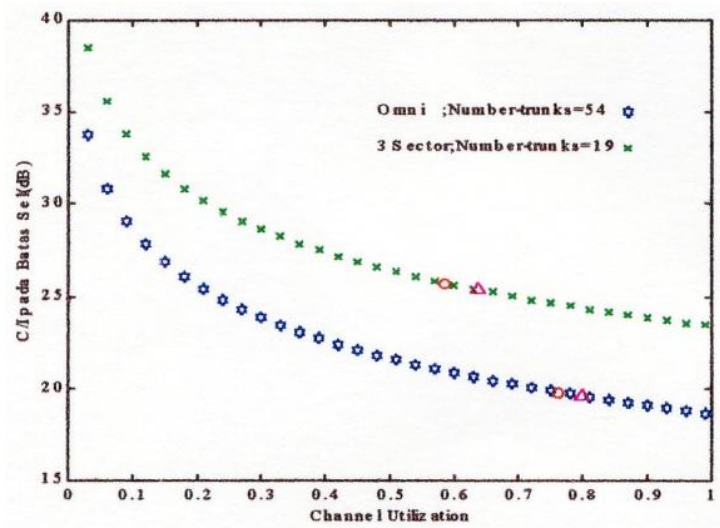

Gambar 7. C/I pada Batas Sel (dB) sebagai fungsi dari Channel Utilization ("O” untuk $P_{\text {block }}=1 \%$; " $\triangle$ " untuk $P_{\text {block }}=2 \%$ )

Gambar 7 menampilkan hasil perhitungan $C / I$ pada batas sel sebagai fungsi dari pemakaian kanal (channel utilization) untuk sistem AMPS yang menggunakan antena omnidirectional dan antena 3 seckr.

Untuk channel utilization yang sama, penggantian antena omnidirectional menjadi antena 3 sector akan menaikkan harga $C / I$ pada batas sel, dengan kata lain Fading Margin sistem akan naik atau kinerja sistem meningkat. Sebaliknya akan terjadi pengaruh yang berlawanan dengan kondisi di atas, jika dipilih $P_{\text {block }}$ sistem AMPS lebih besar. 


\subsection{Throughput Pada Sistem CDPD}

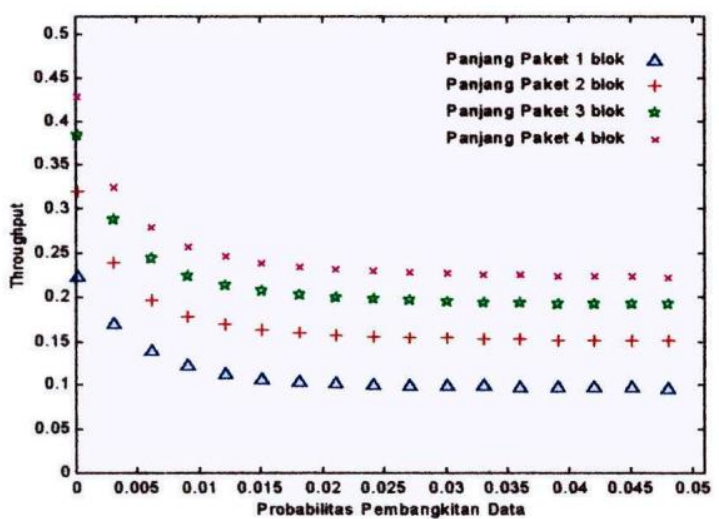

Gambar 8. Throughput sebagai fungsi dari Peluang Pembangkitan Data

$(N=54$ ch.; Omni-D; $\varepsilon=0,05 ; 1 / \beta=20)$

Gambar 8 dan Gambar 9 menampilkan hasil perhitungan throughput sebagai fungsi dari Peluang $\varepsilon$, rataan delay karena proses retranmisi $1 / \beta$ slot yang sama, untuk panjang paket yang bervariasi dan jenis antena yang berbeda.Pembangkitan Data, untuk block error rate (persamaan (7)-(19)).

Pada kondisi steady state, untuk panjang paket yang sama, kenaikkan peluang pembangkitan data tidak berpengaruh terhadap throughput. Pada peluang pembangkitan data dan panjang paket yang sama, pemilihan antena sektor akan menaikkan throughput.

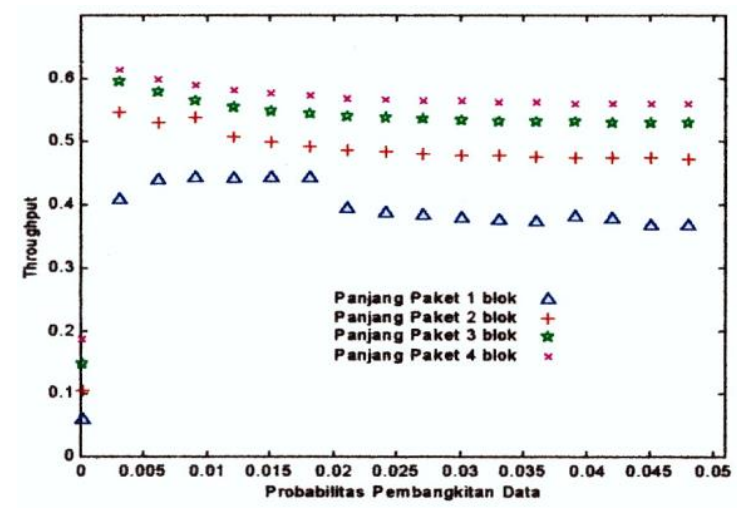

Gambar 9. Throughput sebagai fungsi dari Peluang Pembangkitan Data

$(N=19$ ch.; 3 sector; $\varepsilon=0,05 ; 1 / \beta=20)$

\subsection{Delay rata-rata Pada Sistem CDPD}

Gambar 10 menampilkan hasil perhitungan penaruh panjang paket terhadap karakteristik delay throughput dengan block error rate dan rataan delay retransmisi yang sama, untuk panjang paket yang bervariasi (Persamaan (7),(20)-(22)).

Untuk panjang paket tertentu, sebelum harga throughput maksimum, delay rata-rata naik secara perlahan, tetapi setelah harga throughput melewati harga maksimum, delay rata-rata naik secara tajam.

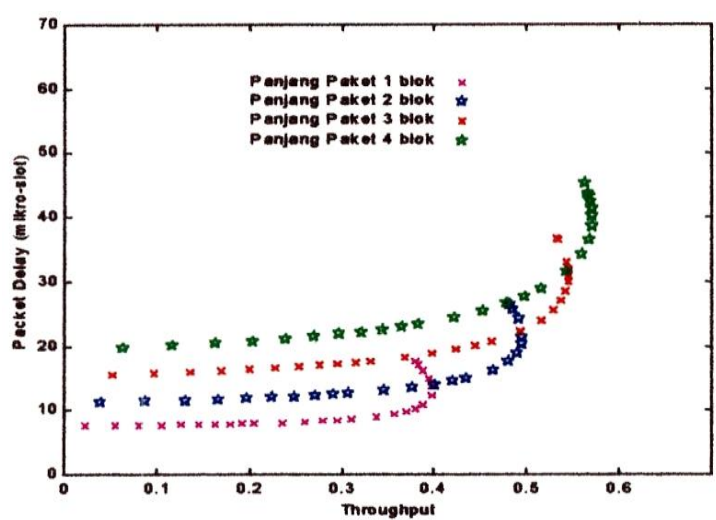

Gambar 10. Karakteristik Delay dari Paket Data sebagai fungsi dari Throughput $(N=19 \mathrm{ch}$;

3 sector; Block Error Rate $=0,05 ; 1 / \beta=20$ )

\subsection{Rugi-rugi Trafik Suara Ternormalisasi}

\subsubsection{Rugi-rugi Trafik Suara Ternormalisasi untuk Sistem Dedicated Channel}

Tabel 2 menampilkan perbandingan trafik suara maksimum yang dapat dilayani tanpa sistem CDPD dan dengan sistem CDPD algoritma dedicated channel.

Tabel 2. Perbandingan Trafik Suara Maksimum Tanpa Sistem CDPD dan Dengan Sistem CDPD (St. Dev. $C / I=6,7 \mathrm{~dB}$ )

\begin{tabular}{|c|c|c|c|c|c|c|}
\hline $\begin{array}{l}\text { No. } \\
\text { Ch. }\end{array}$ & $P_{\text {block }}$ & $Q_{\text {awal }}$ & $\begin{array}{c}\text { Trafik } \\
\text { Max } \\
\text { Awal } \\
\text { (Erlangs) }\end{array}$ & $\begin{array}{c}\text { Trafik } \\
\text { Max } \\
\text { Suara } \\
\text { (Erlangs) }\end{array}$ & $\begin{array}{c}\text { Kanal } \\
\text { "D" }\end{array}$ & $\begin{array}{c}\text { Trafik } \\
\text { Suara } \\
\text { Karena } \\
\text { CDPD } \\
\text { (Erlangs) }\end{array}$ \\
\hline \multirow{6}{*}{19} & \multirow{3}{*}{0,01} & 0,956 & 11,1187 & 11,1187 & 1 & 10,441 \\
\hline & & 0,956 & 11,1187 & 11,1187 & 2 & 9,661 \\
\hline & & 0,956 & 11,1187 & 11,1187 & 3 & 8,881 \\
\hline & \multirow{3}{*}{0,02} & 0,952 & 12,0942 & 12,0942 & 1 & 11,491 \\
\hline & & 0,952 & 12,0942 & 12,0942 & 2 & 10,661 \\
\hline & & 0,952 & 12,0942 & 12,0942 & 3 & 9,831 \\
\hline \multirow{6}{*}{54} & \multirow{3}{*}{0,01} & 0,881 & 41,0959 & 41,0486 & 1 & 40,288 \\
\hline & & 0,881 & 41,0959 & 41,0486 & 2 & 39,528 \\
\hline & & 0,881 & 41,0959 & 41,0486 & 3 & 38,768 \\
\hline & \multirow{3}{*}{0,02} & 0,876 & 43,121 & 42,676 & 1 & 41,886 \\
\hline & & 0,876 & 43,121 & 42,676 & 2 & 41,096 \\
\hline & & 0,876 & 43,121 & 42,676 & 3 & 40,306 \\
\hline
\end{tabular}

Pemilihan jumlah kanal "D" sangat mempengaruhi jumlah layanan trafik suara, terutama jika dilihat antena sektor. Tetapi jika antena omnidirectional yang digunakan, untuk $P_{\text {block }}$ 0,01 dan 0,02 daerah cakupan kurang dari 90\%, sehingga untuk mempertahankan kualitas sinyal perlu ada pengurangan trafik suara.

\subsubsection{Rugi-rugi Trafik Suara Ternormalisasi untuk Sistem Frequency Hopping}

Gambar 11 menampilkan hasil perhitungan rugi-rugi trafik suara ternormalisasi sebagai fungsi C/I ${ }_{\text {threshold }}$ untuk algoritma dedicated channel dan frequency hopping, dengan parameter trafik sama. 
Pada C/I threshold yang rendah, algoritma frequency hopping lebih baik dari algoritma dedicated channel, karena tidak menyebabkan rugirugi trafik suara. Tetapi pada $C / I_{\text {threshold }}$ yang tinggi terjadi kondisi sebaliknya, dimana semakin tinggi $C / I_{\text {threshold }}$ yang diterapkan, semakin tinggi pula rugi-rugi trafik yang terjadi.

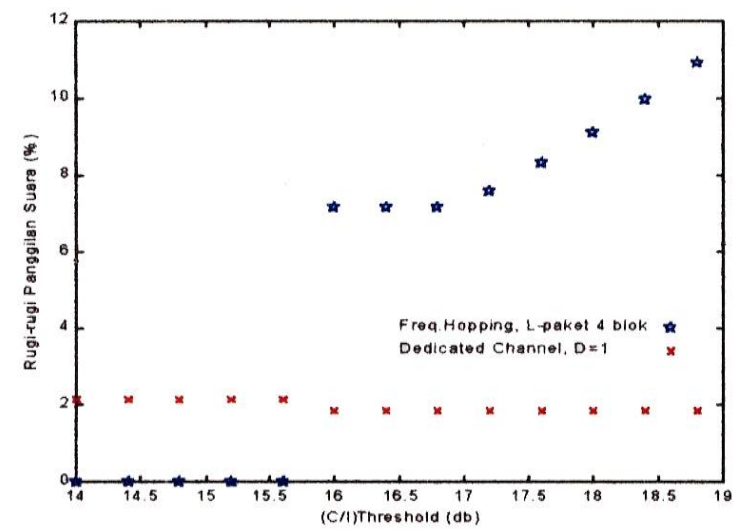

Gambar 11. Rugi-rugi Trafik Suara Ternormalisasi sebagai Fungsi dari $C / I_{\text {threshold }}(N=54 \mathrm{ch}$; Omni-D; $\gamma=40 ; P_{\text {block }}=0,02 ; \varepsilon=0,05 ; 1 / \beta=20 ;$ St. Dev. $C / I=8,48 \mathrm{~dB} ; P_{\text {gen-message }}=0,09 ; N_{\text {back log }}=27$ )

\section{Kesimpulan}

Pada penerapan algoritma Dedicated Channel, karena trafik data CDPD menempati suatu kanal tertentu, pengaruhnya terhadap trafik suara sangat besar, untuk kanal D $=1, P_{\text {block }}=2 \%$ dan kanal AMPS $=54$ ch., maka $P_{\text {bloc }}$ akan naik sebesar 25,5 \%. Jika ditinjau dari jumlah trafik suara maksimum yang dapat dilayani sistem selular tanpa ada trafik data dan dengan adanya trafik CDPD, juga terjadi penurunan tetapi relatif kecil.

Penerapan algoritma Frequency Hopping pada sistem CDPD tidak penyebabkan perubahan $P_{\text {block }}$ trafik suara, karena data menggunakan kanal sistem selular yang tidak dimanfaatkan oleh trafik suara, dan kanal yang sedang digunakan oleh trafik data tetap dianggap kosong oleh trafik suara. Hal ini akan meningkatkan penggunaan kanal (channel utilization) sistem selular, sehingga $C / I$ pada batas sel turun, dengan kata lain kualitas suara turun.

Penggunaan antena sektor menyebabkan kinerja sistem CDPD menjadi lebih baik jika dibandingkan dengan penggunanaan antena omnidirectional. Selain itu akan memperluas "daerah" C/I threshold yang tidak terpengaruh oleh penerapan CDPD, tetapi menyebabkan rugi-rugi trafik suara ternormalisasi yang lebih tinggi dari pada penggunaan antena omnidirectional.

\section{Daftar Pustaka}

[1] Asawa,M and W.E. Stark, 1995, Throughput Analysis of Cellular Digital Packet Data with Applica-tions to Intelligent Transportation Systems, 1995 IEEE 45th Vehicular Technology Conference Countdown to the Wireless 21st Century, New York, IEEE.

[2] Brodsky, I, 1995, Wireless : The Revolution in Persornal Telecommunications, Norwood, MA: Artech House.

[3] Budka,K,C, 1995, Cellular Digital Packet Data Advanced Mobile Phone Standard Network Bandwidth Contention, Proceedings of the 34 th IEEE Conference on Decision and Control, New York.

[4] Budka,K,C, 1995, Cellular Digital Packet Data: Channel Availability, 6th IEEE International Symposium on Personal, Indoor and Mobile Radio Communications, New York.

[5] Calhoun, G, 1988, Digital Cellular Radio, Norwood, MA: Artech House.

[6] Kleinrock, Leonard, 1976, Queueing System, Vol. I, New York, John Wiley \& Sons.

[7] Lee, W. C. Y, 1995, Mobile Cellular Telecommunications, Analog and Digital Systems, 2nd ed, McGraw-Hill.

[8] Mehrotr, A, 1994,Cellular Radio Performance Engineering, Norwood, MA : Artech House.

[9] Paetsch, M, 1993, Mobile Communications in The US and Europa : Regulation, Technology and Markets, Norwood, MA : Artech House.

[10] Sreethan, M and R Kumar, 1996, Cellular Digital Packet Data, Norwood, MA: Artech House. 